\title{
VISIONS AND REVISIONS: THE PERCIPIENCE OF FLORENCE NIGHTINGALE
}

\author{
VISÕES E REVISÕES: O DISCERNIMENTO DE \\ FLORENCE NIGHTINGALE
}

\section{VISIONES Y REVISIONES: EL DISCERNIMIENTO DE FLORENCE NIGHTINGALE}

\author{
Christine E. Hallett ${ }^{1}$
}

How to cite this article: Hallett CE. Visions and revisions: the percipience of Florence Nightingale. Rev baiana enferm. 2021;35:e42139.

\section{Introduction}

Florence Nightingale is widely recognised as one of the nineteenth century's greatest polymaths, with expertise ranging from statistics to sanitary science, from social policy to religious mysticism. But the subject for which she is best known - nursing - is also that about which she is most often misunderstood. Nightingale was not only an experienced nurse; she was also one of the nineteenth century's most prolific writers on the subject. From her apparently simple but ultimately ground-breaking manual, Notes on Nursing, through her circular letters written for her Nightingale School probationers, to official reports in which she offered recommendations to the governments of her day, Nightingale's writings are voluminous and wide-ranging. In my efforts to decode their contents, I am indebted to literally dozens of Nightingale scholars, including biographers such as Mark Bostridge, whose achievement in unpicking both hagiography and deliberate denigration is unsurpassed ${ }^{(1)}$; nurse historians such as Carol Helmstadter, who has enabled a better understanding of the context in which Nightingale's work was produced ${ }^{(2-7)}$; and meticulous empiricists such as Lynn McDonald, whose sixteen-volume compilation of Nightingale's writings has done so much to break open the vast field of Nightingale studies ${ }^{(8-11)}$. But Florence Nightingale's ideas - and, indeed, her ideals - can only really be understood through a close and detailed scrutiny of her own writings.

But where to start? The corpus of Nightingale's writings is vast. Even the student who attempts to analyse only on those texts that relate directly to nursing faces a daunting task. And this is, perhaps, why Nightingale has been so frequently misunderstood - this, and the tendency for some Nightingale scholars to fall into the twin traps of academic ambition and undue haste.

Professor of Nursing History at the University of Huddersfield, Chair of the UK Association for the History of Nursing and President of the European Association for the History of Nursing. http://orcid.org/0000-0002-5916-4785. C.Hallett@hud.ac.uk 
A failure to focus on Nightingale's own writings has, at times, resulted in the publication of ostensibly new findings that merely repeat old errors. If only to pass over his work as quickly as possible, I shall mention F. B. Smith ${ }^{(12)}$ at this point, along with the service that was done to nursing history by Lynn McDonald's careful (if rather outspoken) dismantling of his empirically ungrounded arguments ${ }^{(12-13)}$. Beyond Smith's obvious errors lies a community of historians particularly medical historians - whose failure to understand Nightingale's work on its own terms has translated into a series of misleading assertions that Nightingale's ideas about health and disease (and most particularly about infectious diseases) were both ambiguous and confusing ${ }^{(14-16)}$. This paper will reconsider Nightingale's own works by relating them to the social, intellectual and spiritual context of her time. My contention is that, when taken in context, Nightingale's views on nursing were coherent, consistent and practical. In reconsidering Nightingale's ideas - as expressed by herself - this paper will also revisit some of the Nightingale controversies, and, in doing so, it will suggest that Nightingale's detractors failed to recognise both the consistency of her ideas and her capacity to adapt her thinking in response to the changing medical perceptions of her day.

One means of understanding Nightingale's ideas and ideals is to trace their origins in three influential currents of thought. The first is a peculiarly British, Victorian and Anglican belief in a divine plan that could only be implemented by godly human beings, or, in other words, the powerful current of thought embedded in Victorian culture that held that 'God helped those who helped themselves' - which mobilised around so-called 'muscular Christianity'(17). The second is a scientific milieu (at least among the middle classes) that encouraged members of the medical professions to theorise about the nature of disease ${ }^{(18)}$. In expounding on the concepts 'health' and 'disease', Nightingale in common with many of her medical contemporaries trod warily across the medical orthodoxies of her day, and has, in consequence, been accused of reluctance in accepting the reality of infection, when, in fact, she showed a remarkable percipience in warning against an unthinking adoption of 'germ theory'. The third is what I might call a prototype feminism that draws in part upon earlier writings, such as those of Mary Wollstonecraft and Charlotte Bronte and which had a deep influence on the ways in which she shaped nursing as a profession for women ${ }^{(19)}$.

\section{Nightingale's vision of humanity's divine purpose}

Florence Nightingale was, famously, convinced that she had been 'called by God' at the age of 16, to serve humankind ${ }^{(20: 54-5)}$. It had taken her many years first to find an outlet for the powerful urge to do 'good works' that followed that call, and then to persuade her family to permit her to pursue nursing. Following her initial experiences in Germany, Paris and London, and her famous expedition to the Crimea, she began to formulate her ideas in a succession of writings. An enforced illness following a serious and life-threatening bout of Crimean fever - an illness which has convincingly been identified as the milk-borne infection, brucellosis - kept her confined to her rooms (often to her bed $)^{(21: 282-21)}$, an imprisonment which, paradoxically, liberated her to spend her time working out her philosophies of healthcare and social reform ${ }^{(22-25)}$.

In her Notes on Nursing, Nightingale drew upon her philosophy of human responsibility. "God lays down certain physical laws", she retorted in her chapter on Health of Houses, adding, "Upon His carrying out such laws depends our responsibility... Yet we seem to be continually expecting that He will work a miracle, i.e., break his own laws expressly to relieve us of responsibility" (26:17). In a draft letter identified by Lynn McDonald as having been intended for her father, Nightingale set out her philosophy of God's divine purpose for humanity:

The same tie really connects us to every one of our fellows as the tie which connects us with God... To neglect or ill use the imbecile old woman, the dirty child, is the same crime of lese majeste against the 
Almighty that blasphemy of God is. I think that love to mankind ought to be our one principle in the Poor law - not philanthropy - philanthropy is the biggest humbug I know ${ }^{(27: 434)}$.

In condemning philanthropy as the opposite of genuine reform, Nightingale identified the hypocrisy at the heart of Victorian society - a hypocrisy that enabled members of a wealthy and privileged governing elite to enhance their own egos - both individual and collective without actually improving the lives of those they claimed to support.

Nightingale's writings on the reform of Poor Law infirmaries reveal a vision for social reform that was ahead of its time. Her perspective foreshadowed that of Beatrice and Sidney Webb in their Minority Report on the Poor Law, published in $1909^{(9: 428)}$. Nevertheless, despite her best efforts to secure the provision of expert nursing for patients in Poor Law hospitals, the Metropolitan Poor Act ${ }^{(1857)}$ was a disappointment, and Nightingale was left with only one option: to reform Poor Law nursing hospital-by-hospital - a laborious and often unsuccessful endeavour. Her first experiment, which was conducted with the financial and practical assistance of reformer, William Rathbone, involved the placing of the devout and self-sacrificing Agnes Jones at the head of a small group of nurses at the Brownlow Hill Infirmary in Liverpool. Jones struggled to bring order and efficiency to the chaos of the infirmary wards, dying in the attempt, and evoking an outpouring of admiration from Nightingale, whose best-known writing on Jones, Una and the Lion, was both a hagiographic account of the unnamed paragon (who had been so selfeffacing that she had, in fact, asked not to be named) and a 'call to action' to other young women ${ }^{(28)}$. Nightingale's second experiment, the appointment of Elizabeth Torrance at the new Highgate Infirmary in 1868 was more successful in the longer term ${ }^{(9: 428-9)}$.

\section{Nightingale's vision of the centrality of nursing in the care and cure of patients}

Nightingale expressed forthright views on the nature of disease and the role of nursing in its eradication. In her well-known treatise, Notes on Nursing she declared that "all disease, at some period or other of its course, is more or less a reparative process, not necessarily accompanied with suffering: an effort of nature to remedy a process of poisoning or of decay"(26). Whilst in some ways quite singular, this view was not incompatible with the mindsets of mid-nineteenth-century medical scientists, who still adhered to the eighteenth century medical teachings that any given episode of ill-health was caused by one of two processes: inflammation or putrefaction. Put simply, inflammation was understood as a mechanical failure of the circulation, and putrefaction was understood as a stagnation of body fluids. These closely connected theories were seen as highly enlightened, having superseded the preceding views of medieval doctors that disease was caused merely by imbalance in four bodily fluids known as humours ${ }^{(18)}$. The mechanistic view of the "inflammationists" were particularly fashionable, and Nightingale's view that disease was an adaptive process interlocked well with this perspective.

Nightingale also had clear views on the nature of bodily symptoms, pointing out that these were not necessarily the consequences of disease processes, but more often, the result of the conditions under which individuals lived. Discomfort, she argued, was likely to be a consequence of "the want of fresh air, or of light, or of warmth, or of quiet, or of cleanliness, or of punctuality and care in the administration of diet, of each or of all of these" (26:2) . But, she added, anomalies arising out of these lapses could rapidly become a process of poisoning or decay leading to disease. For today's experts in health promotion her ideas have a strongly contemporary resonance, as if she was, somehow, ahead of her time. But such an interpretation is quite naïve: Nightingale's thinking was immersed in the medico-scientific context of her day. Her focus on six cardinal health-giving principles - fresh air, light, warmth, rest, cleanliness and nutrition - arose out of her acceptance of theories of inflammation and 
putrefaction, rather than a foreshadowing of our modern focus on the supposed origin of diseases in organic lesions.

In common with other nurse-leaders of her day, Nightingale was anxious to identify nursing as a profession very different from medicine, with its own peculiar emphases. Where the surgeon's focus was repairing limbs and removing "external blockages", and the physician's medicine was designed to remove "internal blockages", the work of the nurse was much more complex. Her job was to regulate both the external environment and internal condition of the patient to ensure that neither damage nor blockage ever happened, or, if it did, that nature was able to clear the condition. And this emphasis on enabling nature to restore health, along with an insistence that it would indeed do so, if the clinician merely provided the right conditions for it to proceed, was absolutely key to Nightingale's philosophy. Fresh air, light, warmth, rest, cleanliness and nutrition were not cures; they were nature's enablers, and therefore far more important than any medical treatment.

One of the accusations levelled at Nightingale by medical historians is the suggestion that she rather truculently refused to accept the idea that infective microorganisms, referred to as 'germs' were the causative agents in many of the most common nineteenth-century diseases. This view has probably originated in a failure to read beyond Notes on Nursing, a book written in 1859, when germ theory was still a new and largely unproven theory. It was only after Robert Koch's work in the 1880s that medical science adopted germ theory wholesale, and it was soon after this that Nightingale herself came to accept it. In Notes on Nursing, she ridiculed that idea that diseases were "separate entities which must

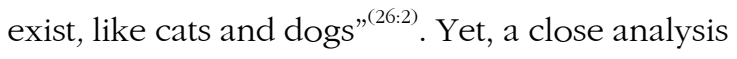
of her later writing on this subject suggests that, once she had been made aware of the evidence, Nightingale not only accepted germ theory, but also actually promoted it, particularly among her own students. In an 1897 circular letter to her probationers, she advised:

\begin{abstract}
Let me note here, in passing, every year we know more of the great secrets of nursing. One is the aseptic... we have been eminently taught this aseptic by our doctors and surgeons in their operating theatres. We have to carry it out in our nursing. Septic means blood poisoning; antiseptic means using certain substances supposed to counteract blood poisoning. Aseptic means doing away with everything that can possibly produce blood poisoning. Aseptic means absolute cleanliness. A great doctor, a friend of mine, says, 'Call it germs, bacillus or dirt, the treatment is the same, that is, cleanliness, ${ }^{(29: 871-2)}$.
\end{abstract}

More recently, it has become clear that even Nightingale's earlier pre-germ-theory writings contained much common sense. In Notes on Nursing, she demonstrated considerable prescience, pointing out that a simplistic adherence to germ theory would lead to a tendency to offer apparently quick and simple answers to complex environmental questions. Her perspective was vindicated by the twentieth century's reliance on "magic-bullets" such as antibiotics, rather than a sufficiently close attention to diet, housing and poverty - factors which - as Nightingale had pointed out - were the real generators of disease.

In the 1850s, Nightingale had pointed out how difficult it would be to employ good doctors and nurses if "germ theory" took hold of the collective consciousness:

\begin{abstract}
Does not the popular idea of 'infection' involve that people should take greater care of themselves than of the patient? That, for instance, it is safer not to be too much with the patient, not to attend too much to his wants? Perhaps the best illustration of the utter absurdity of this view of duty in attending on 'infectious' diseases is afforded by what was very recently the practice, if is not so even now, in some of the European lazarets - in which the plaguepatient used to be condemned to the horrors of filth, overcrowding, and want of ventilation, while the medical attendant was ordered to examine the patient's tongue through an opera-glass and to toss him a lance to open his abscesses with? True nursing ignores infection, except to prevent it... Wise and humane management of the patient is the best safeguard against infection ${ }^{(26)}$.
\end{abstract}

Nightingale has been accused of being, essentially, a miasmatist - of adhering to an out-of-date philosophy of disease-causation. She certainly emphasised the need for fresh air, referring to it as "the very first canon of nursing". Essentially, she argued that the air in a patient's room must be "kept as pure as 
the external air, without chilling him"(25:6). Providing warmth was just as difficult, because "to attempt to keep a ward warm at the expense of making the sick repeatedly breathe their own hot, humid, putrescing atmosphere is a certain way to delay recovery or to destroy life"(26:8-9). In her philosophy of health and disease, both pure air and warmth were required to prevent both putrefaction and a "loss of vital heat by the patient himself"(26:10), and to "carry off the effluvia" produced by the $\operatorname{sick}^{(26: 13)}$. Light was also essential, she added, pointing out that its absence resulted in "scrofula, rickets etc, among the children"(26:70-71).

Nightingale emphasised the need for pure water and good nutrition- both commodities very difficult to find for the nineteenth century's sick-poor. She also pointed out that the feeding of helpless patients - a task that appeared So simple - was, in fact, one of the most complex elements of the work. She commented, "that thousands of patients are annually starved in the midst of plenty, from want of attention to the ways which alone make it possible for them to take food" ${ }^{\text {(26:50) }}$.

In recognising the link between sleep and health, Nightingale was, perhaps, ahead of her time. Beyond this, she also identified the need for a restful environment and an attitude in the nurse that would promote quiet and calm. In one of her typically quirky statements, she condemned the wearing of crinolines by nurses, pointing out that "a nurse who rustles is the horror of a patient"(26:36).

\section{Nightingale's vision of women's role and purpose}

Among the charges levelled at Florence Nightingale during the late twentieth and early twenty-first centuries are those of anti-feminism and race discrimination. Accusations of racism have been effectively dispensed with by scholars who have examined the empirical evidence relating to Nightingale's relationship with Mary Seacole at Scutari, which appears to have been both polite and cordial ${ }^{(6 ; 20)}$.
Charges of anti-feminism are more difficult to evaluate - until one realises just how entrenched were the patriarchal views of British Victorian society. An examination of some of Nightingale's writings in the context of her own time has revealed what has subsequently been identified as a powerful "proto-feminist" strain in her work. So, was Nightingale an "antifeminist" or a "proto-feminist"? A reading of her essay, Cassandra, offers persuasive evidence that she was a "feminist before her time". Ray Strachey was so impressed by Cassandra that she included the entire work as an appendix to her history of the British "Women's Movement": The Cause ${ }^{(18)}$.

Cassandra is a highly personal work, revealing of Nightingale's own struggles with her identity as an English Victorian lady. "Passion, intellect, moral activity - these three have never been satisfied in a woman", she declared ${ }^{(18: 398)}$. In one particularly revealing passage, she likened female intellect to light of the moon:

\begin{abstract}
Women often strive to live by intellect. The clear, brilliant, sharp radiance of intellect's moonlight rising upon such an expanse of snow is dreary, it is true, but some love its solemn desolation, its silence, its solitude... But a woman cannot live in the light of intellect. Society forbids it. Those conventional frivolities, which are called her 'duties' forbid it... What are these duties (or bad habits)? - Answering a multitude of letters which lead to nothing, from her so-called friends, keeping herself up to the level of the world that she may furnish her quota of amusement at the breakfast-table; driving out her company in the carriage. And all these things are extracted from her by her family... What wonder, if wearied out, sick at heart with hope deferred, the springs of will broken, not seeing clearly where her duty lies, she abandons intellect as a vocation and takes it only, as we use the moon, by glimpses through her tight-closed window shutters? ${ }^{(18: 404)}$
\end{abstract}

Cassandra is a controversial and avant-garde text, in which Nightingale emphasises what she views as the suppression of all that is positive and energetic in the women of her time. She goes so far as to declare that "Christ, if $\mathrm{He}$ had been a woman, might have been nothing

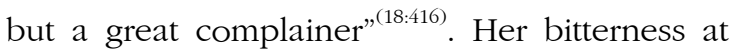
attempts to suppress her own intellectual power is evident, as is her solution to the problem: she clearly views nursing the perfect outlet for her suppressed energies - and those of other 
Victorian women. Indeed, Nightingale, like many nurses and doctors of her day, saw nursing as peculiarly suited to the propensities and abilities of women.

Nightingale's deliberately feminine (as distinct from feminist) language is particularly apparent in her addresses to her own Nightingale School nurses. In a circular letter dated June 1897 she emphasised the healing power of "intelligent loving kindness", adding that patients have "the right to expect" nursing care which is infused with "kindness, consideration, gentleness, courtesy, refinement" ${ }^{(29: 877)}$. She also added, however, that firmness of character must accompany such gentle qualities, illustrating the power of such firmness by pointing out how reformed nurses have transformed the ambience of workhouse infirmary wards:

I will not go back to the time when, in the old
workhouses, the favourite Sabbath amusement of
the sick male wards was to shy their tin plates and
cups at each other across the ward, and then send
for the police and give each other into custody. In
many an infirmary the policeman might have almost
been called the night nurse. All that disappeared
at once with the educated and trained nurse. She
became the powerful policeman. She is the salt of
the wards

Nightingale's claims that nurses had, by 1897 , completely transformed the social atmosphere of the workhouse infirmaries is, perhaps, slightly excessive, although there is evidence to support her claim that these hospitals were no longer the places of dread they had been in the mid nineteenth century ${ }^{(30)}$. What is, perhaps, most significant in this quotation, though, is the claim that the new, reformed nurse exercised not only loving-kindness, but also the strength and personal power of a police officer: a strength sufficient to quell the dangerous riotousness of the nineteenth century hospital ward. Even more significant is that Nightingale so deliberately identified the origins of nursing character in both education and training. Nightingale was clearly in favour of women's education, though she also clearly believed that the training of nurses could be dangerously tainted by too heavy a reliance on "book learning" to the neglect of hands-on skills and moral guidance:
There is no doubt that this is a critical time for nursing. Will you have women, or will you have words? Which nurse best?... There appears to be some danger of our being suffocated with words, or our thinking that we can learn nursing in six ambulance classes... Nursing takes a whole life to learn. We must make progress in it every year. It takes five years, not of words, but of practice, to make a ward sister. There seems some danger that the twentieth century will be an age not of facts, but of enthusiasms without facts ${ }^{(29: 877)}$.

It is in this wariness of "book learning" that later academics have found elements of what they see to be Nightingale's prejudice against nurseeducation and thus against education of women more generally. This, in turn, has fuelled modern debates about whether nurses should perform "menial tasks". In a controversial footnote in Notes on Nursing, Nightingale gives detailed instruction on the emptying of "chamber utensils":

\footnotetext{
If a nurse declines to do these kinds of things for her patient, 'because it is not her business', I should say that nursing was not her calling. I have seen surgical 'sisters', women whose hands were worth to them two or three guineas a week, down upon their knees, scouring a room or hut, because they thought it otherwise not fit for their patients to go into. I am far from wishing nurses to scour. It is a waste of power. But I do say that these women had the true nurse-calling - the good of their sick first, and second only the consideration what it was their 'place' to do - and that women who wait for the housemaid to do this, or for the charwoman to do that, when their patients are suffering, have not the making of a nurse in them ${ }^{(26: 14)}$.
}

Yet, alongside Nightingale's assertion that a nurse should not refuse to scrub floors if it were really necessary is an emphasis on the ability to manage assistants and servants. The nurse, Nightingale pointed out, must possess the "art of multiplying herself". Trying to do everything oneself (except in the type of emergency situation described above) would only result in poor work and a neglect of the patient ${ }^{(26: 25)}$.

In her 1897 lecture to her nurses, Nightingale offered a more considered definition of what nursing knowledge should entail:

The patient is to us a threefold interest: the intellectual interest as a case, which requires the closest observation of facts, to be explained by the lecture and the clinical teaching; the moral interest, as a fellow creature to whom we must do, while under our care, either moral good or moral harm; the technical interest, whereby we learn what to do for the patient, and how to do it ${ }^{(29: 879)}$. 
Nightingale's perspective on the complexity of nursing - an art so complex that it could not be learned from a book - is clearly laid-out in her contribution to William Rathbones' Sketch of the History and Progress of District Nursing. She argued that,

The tendency is now to make a formula of nursing, a sort of literary expression. Now, no living thing can less lend itself to a 'formula' than nursing. Nursing has to nurse living bodies and spirits. It cannot be formulated like engineering. It cannot be numbered or registered like arithmetic or population. It must be sympathetic.. The nurse's art cannot be made a formula any more than the painter's. The great painter Fuseli was examined as to how he mixed his colours. 'With brains, Sir' was his answer. The good nurse can often only answer, if examined how she nurses, 'with brains and heart, Sir, and with training and practice, (31:822).

\section{Conclusion}

This paper has identified the underlying consistency and coherence in Florence Nightingale's thinking, by focusing on three significant strands in her writings: muscular Christianity, nineteenth-century medical science, and proto-feminism. Although each of these strands was powerful, it was Nightingale's capacity to capture them in one almost-impossibly encompassing vision of professional nursing that both opened-up previously unheard-of possibilities for Victorian women and helped lay the foundations for a profession that would provide safe and compassionate patient care for the next two centuries. Although her work was very complex, Nightingale believed it was the outcome of a very simple mission: to relieve suffering and enhance care. In a letter dictated to her esteemed colleague, Dr. John Sutherland, around 1867, Nightingale set out herlife's work:

My life is spent in trying to introduce a great reform in the care and management of the sick and suffering. This is my work. I have proclaimed it, written about it, advertised about, printed about, in short, I have done everything I can to lend it my name and influence. And, while I have done this, publicly, I have privately exhorted, advised and aided those who were willing to work in the same direction but did not happen to know the way so well as I do ${ }^{(27: 434)}$.

\section{Collaborations:}

1 - conception, design, analysis and interpretation of data: Christine E. Hallett;
2 - writing of the article and relevant critical review of the intellectual content: Christine E. Hallett;

3 - final approval of the version to be published: Christine E. Hallett

\section{Reference}

1. Bostridge M. Florence Nightingale: The Woman and Her Legend. London, Viking, 2008.

2. Helmstadter C. From the Private to the Public Sphere: The First Generation of Lady Nurses in England, Nursing History Review, 9 (2001): $127-40$.

3. Helmstadter C. Early Nursing reform in nineteenth-century London: a doctor-driven phenomenon. Medical History, 46 (3) 2002: 325-350.

4. Helmstadter C. A Real Tone: Professionalising Nursing in Nineteenth-Century London. Nursing History Review, 11, 2003: 3-30.

5. Helmstadter C. Shifting boundaries: religion, medicine, nursing and domestic service in mid-nineteenth-century Britain. Nursing Inquiry, 16 (2) 2009: 133-143.

6. Helmstadter C. Navigating the Political Straits in the Crimean War in SN; Rafferty AM Eds.) Notes on Nightingale: The Influence and Legacy of a Nursing Icon. Ithaca, Cornell University Press, 2010: $28-54$.

7. Helmstadter C. Beyond Nightingale: Nursing in the Crimean War. Manchester, Manchester University Press, 2019.

8. McDonald L. The Collected Works of Florence Nightingale. Wilfrid Laurier University Press, Waterloo, Ontario, 2001-2012.

9. McDonald L. Florence Nightingale on Public Health Care. Volume 6 of the Collected Works of Florence Nightingale. Waterloo, Ontario, Wilfrid Laurier University Press, 2004.

10. McDonald L. Florence Nightingale: Extending Nursing: Volume 13 of the Collected Works of Florence Nightingale. Guelph University Press, Waterloo, 2009.

11. McDonald L. The Crimean War. Volume 14 of the Collected Works of Florence Nightingale. Waterloo, Ontario, Wilfrid Laurier University Press, 2010. 
12. Smith FB. Florence Nightingale: Reputation and Power. London, Croom Helm 1982.

13. McDonald L. Florence Nightingale at First Hand. London, Continuum, 2010.

14. Ackerknecht E. Anti-Contagionism Between 1821-1867. Bulletin of the History of Medicine, 22, 1948: 568-93;

15. Rosenberg C. Florence Nightingale on Contagion: The Hospital as Moral Universe in Rosenberg, Charles, (ed.) Healing and History: Essays for George Rosen. New York, Science History, 1979.

16. Vogel M.; Rosenberg C. The Therapeutic Revolution: Essays in the Social history of American Medicine. Philadelphia, University of Pennsylvania Press, 1979.

17. Ellisor S. Florence Nightingale"s Cassandra: The Prophet"s Predecessors and Descendants. Unpublished MA Thesis. The University of Georgia, Athens, Georgia, 2005. Available at: getd.libs.uga. edu/pdfs/ellisor_sarah_p_200508_ma.pdf.

18. Hallett C. The Attempt to Understand Puerperal Fever in the Eighteenth and Early Nineteenth Centuries: The Influence of Inflammation Theory. Medical History, 49 (1) 2005: 1-28.

19. Nightingale F. Cassandra in Strachey R; Nightingale F; Catt CC; Bell and Sons G; Neill \& Co. The Cause: A Short History of the Women"s Movement in Great Britain. Bath, Cedric Chivers, 1928: Appendix 1, pp 395-418.

20. Bostridge M. Florence Nightingale: The Woman and Her Legend. London, Viking, 2008.

21. Young DAB. Florence Nightingale"s Fever. British Medical Journal, 311, 1995: 1697-1700.

22. Cook SET. The Life of Florence Nightingale. London, Macmillan and Co., 1913.

23. Woodham-Smith C.; Nightingale F. 1820-1910. London, Book Club Associates, 1972; first published 1915.
24. Huxley E. Nightingale F. London, Weidenfeld and Nicolson, 1975.

25. Baly M. Florence Nightingale and the Nursing Legacy. London, Whurr Publishers, 1997.

26. Nightingale F. (1859) Notes on Nursing: What It Is and What It Is Not Modern Edition. Edinburgh, Churchill Livingstone, 1980.

27. Nightingale F. Draft Letter in Dr Sutherland"s hand, ADD MSS 45800 204-05 in: Lynn McDonald (ed.) Florence Nightingale on Public Health Care: Volume 6 of the Collected Works of Florence Nightingale. Waterloo, Ontario, Wilfrid Laurier University Press, 2004: 434.

28. Nightingale F. Una and the Lion Good Words, 1 June, 1868: 360-66. Draft quoted in: Lynn MacDonald (ed.) Florence Nightingale on Public Health Care: Volume 6 of the Collected Works of Florence Nightingale. Waterloo, Ontario, Wilfrid Laurier University Press, 2004: 360-66

29. Nightingale F. Address 13: To the Nurses and Probationers Trained under the "Nightingale Fund", Florence Nightingale Museum 1.0277.1 in Lynn McDonald, Florence Nightingale: The Nightingale School: Volume 12 of the Collected Works of Florence Nightingale. Waterloo, Ontario, Wilfrid Laurier University Press, 2009.

30. Fraser D (ed.). The New Poor Law in the Nineteenth Century. London, Macmillan, 1976.

31. Nightingale F. Introduction to the History of Nursing in the Homes of the Poor in Rathbone, W. Sketch of the History and Progress of District Nursing from. Its Commencement in the Year 1859 to the Present Date. London, Macmillan, 1890. Draft in

32. McDonald L.; Nightingale F. extending nursing. Collected Works of Florence Nightingale, Volume 13 Guelph University Press, Waterloo, 2009.

Received: October 21, 2020

Approved: January 19, 2021

Published: February 10, 2021

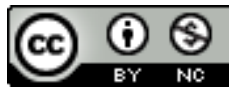

The Revista Baiana de Enfermagem use the Creative Commons license - Attribuition -NonComercial 4.0 International. https://creativecommons.org/licenses/by-nc/4.0/

This article is an Open Access distributed under the terms of the Creative Commons (CC BY-NC).

This license lets others remix, adapt and create upon your work to non-commercial use, and although new works must give its due credit and can not be for comercial purposes, the users do not have to license such derivative works under the same terms. 